\title{
Acquired von Willebrand's disease and hypothyroidism: report of a case presenting with menorrhagia
}

\author{
N.E. Blesing, H. Hambley and G.A. McDonald \\ Department of Haematology, Royal Infirmary, 84 Castle Street, Glasgow G4 OSF, UK.
}

\begin{abstract}
Summary: A 17 year old woman presented with severe anaemia due to menorrhagia. On investigation, she was shown to have abnormalities of her haemostatic mechanism consistent with von Willebrand's disease Type I, although there was no family history of this disorder. In addition, she was shown to have severe primary hypothyroidism. On correction of hypothyroidism with oral thyroxine, her coagulation defects returned to normal and menorrhagia ceased. This is consistent with acquired von Willebrand's disease secondary to hypothyroidism.
\end{abstract}

\section{Introduction}

Menorrhagia and easy bruising are stated to be commonly occurring presenting symptoms in hypothyroidism. $^{1,2}$ Anaemia is found not infrequently in patients with hypothyroidism: in a review of 202 cases, $23 \%$ of female patients and $47 \%$ of male patients were found to be anaemic at presentation. ${ }^{3}$ Despite this, significant blood loss in patients with untreated hypothyroidism has been reported only rarely., ${ }^{4,5} \mathrm{~A}$ possible link between the two could be a haemostatic defect similar to that of von Willebrand's disease which would be present in the untreated state and which would resolve on effective therapy of the hypothyroidism, i.e. acquired von Willebrand's disease. ${ }^{6}$

\section{Case report}

The patient was a 17 year old female who had been well until 10 days previously when she started to menstruate. After 3 days, the blood flow increased and she started to complain of tiredness. She consulted her general practitioner who requested a full blood count which was reported as showing pancytopenia with atypical cells, possibly blasts, seen on the peripheral blood film.

She was referred to the Haematology Department of Glasgow Royal Infirmary for further investigation. On admission, she complained of tiredness and continued to have vaginal blood loss. Although her menstrual cycle was irregular, she had not had menorrhagia in the past. She denied

Correspondence: N.E. Blesing, M.D., M.R.C.P. (UK) Accepted: 3 January 1990 any history of easy bruising, of epistaxis or of excessive blood loss following surgical or dental procedures. There was no family history of a bleeding disorder nor of any thyroid disorder. Apart from oral ferrous sulphate which had been started by her general practitioner at the initial consultation, she was not taking any other medication.

On examination, she was anaemic. Height was $145 \mathrm{~cm}$ and weight was $61 \mathrm{~kg}$. There was no lymphadenopathy nor splenomegaly. Examination of the cardio-respiratory and gastrointestinal system was normal. Apart from some puffiness of her face, there were no other features suggestive of a thyroid disorder. Gynaecological examination was normal.

Investigation of peripheral blood revealed haemoglobin concentration of $52 \mathrm{~g} / \mathrm{l}$, total leucocyte count of $8.5 \times 10^{9} / 1$ and platelet count of $263 \times 10^{9} / 1$. Reticulocyte count was elevated at $9 \%$ and mean red cell volume (MCV) was elevated at $100 \mathrm{fl}$ (the normal range for this laboratory, 76-96 fl). Peripheral blood film showed polychromasia of erythrocytes with an occasional nucleated red cell being seen; leucocytes were normal in type and distribution and, in particular, no blast cells were seen. Bone marrow aspiration yielded only blood. However, trephine biopsy showed a marrow of slightly decreased cellularity but with normal maturation of all cellular elements. Results of investigation of haemostatic system are shown in Table $I$.

Renal and liver function tests were normal. Thyroid function tests were as follows: serum thyroxine (T4) $26 \mathrm{nmol} / 1$ (normal range $55-144 \mathrm{nmol} / \mathrm{l}$ ), serum tri-iodothyronine (T3) $0.8 \mathrm{nmol} / 1$ (normal range $0.9-2.8 \mathrm{nmol} / \mathrm{l}$ ) and 
Table I Results of haemostatic investigation before (Pre Rx with T4) starting therapy with thyroxine and after restoration of euthyroid state (Post $\mathrm{Rx}$ with T4)

Pre Rx Post $R x$ with T4 with T4

\begin{tabular}{lcc}
\hline $\begin{array}{c}\text { One stage prothrombin time } \\
\text { (normal range 12-15 seconds) }\end{array}$ & 15 & 15 \\
$\begin{array}{c}\text { Kaolin cephalin clotting time } \\
\text { (normal range 36-50 seconds) }\end{array}$ & 42 & 43 \\
$\begin{array}{c}\text { Thrombin clotting time } \\
\text { (normal range 6-9 seconds) }\end{array}$ & 8 & 6 \\
$\begin{array}{c}\text { Factor VIIIC } \\
\text { (normal range 50-190 IU/d) }\end{array}$ & 36 & 120 \\
$\begin{array}{c}\text { von Willebrand factor antigen } \\
\text { (normal range } 50-146 \text { IU/dl) }\end{array}$ & 36 & 79 \\
$\begin{array}{l}\text { Ristocetin cofactor } \\
\text { (normal range } 50-172 \text { IU/dl) }\end{array}$ & 31 & 71 \\
$\begin{array}{c}\text { von Willebrand factor multimers } \\
\text { Bleeding time } \\
\text { (normal range } 3-9 \text { min) }\end{array}$ & normal & normal \\
\hline
\end{tabular}

serum thyroid stimulating hormone (TSH) $272 \mathrm{mU} / \mathrm{l}$ (normal range $<5 \mathrm{mU} / \mathrm{l}$ ). Thyroid microsomal antibody and thyroglobulin antibody were negative.

Initial therapy included blood transfusion to correct anaemia and oral thyroxine, initially $50 \mu \mathrm{g}$ daily and gradually increasing to $200 \mu \mathrm{g}$ daily to correct hypothyroidism. On this therapy, she became euthyroid and menstruation became regular with no recurrence of menorrhagia. Haemostatic function (Table I) has returned to normal and the haemoglobin has remained stable without any blood transfusions or haemotinic therapy.

\section{Materials and methods}

Full blood count was performed using Coulter $\mathbf{S}$ Plus (Coulter Electronics Ltd, Bedford). Coagulation studies were performed manually using standard methods. ${ }^{7}$ Factor VIII:C was measured by a One-stage technique. ${ }^{8}$ Von Willebrand factor antigen (vWF:Ag) was assayed by a Laurell technique $^{9}$ and Ristocetin Co-factor (RiCoF) was measured by a platelet aggregation method. ${ }^{10}$ Analysis of multimers of von Willebrand factor (vWF) was performed by SDS polyacrylamide gel electrophoresis. ${ }^{11,12}$ Bleeding time was measured by a template method (Simplate, General Diagnostics, New Jersey, USA).

\section{Discussion}

The patient described above showed defects in her haemostatic system consistent with the diagnosis of von Willebrand's disease, type IA. The main clinical effect of this was menorrhagia which caused severe anaemia requiring blood transfusion. The patient was found to be severely hypothyroid and on correction of the hypothyroid state, the haemostatic defects returned to normal suggesting that the lack of thyroid hormones played a fundamental role in the decreased levels of factor VIII which on multimeric analysis was normal, i.e. there was a quantitative rather than a qualitative defect of factor VIII production.

Acquired von Willebrand's disease has been associated usually with a circulating IgG antibody which acts as a functional inhibitor of the factor VIII molecule and which has been associated with various underlying disorders such as systemic lupus erythematosus, ${ }^{13,14}$ non-Hodgkin's lymphoma ${ }^{15}$ and myeloma. ${ }^{16}$ However, recent reports have indicated that hypothyroidism may cause a decrease in the circulating factor VIII level without the presence of an inhibitor. ${ }^{6,17}$ The precise mechanism is not known; at a cellular level triiodothyronine acts on nuclear receptors to cause an increase in $\mathrm{m}$-RNA sequences ${ }^{18}$ and it is tempting to speculate that, in the presence of reduced levels of thyroid hormone, decreased amounts of $\mathrm{m}$ RNA specific for factor VIII components would lead to a decrease of the synthesis of the factor VIII molecule. The possibility of acquired von Willebrand's disease and hypothyroidism should be kept in mind in patients presenting with menorrhagia. Unexplained bleeding or easy bruising in patients presenting with hypothyroidism should prompt full investigation of the haemostatic system.

\section{Acknowledgement}

The authors would like to thank Professor F.E. Preston, University Department of Haematology, Royal Hallamshire Hospital, Sheffield, who kindly carried out the analysis of von Willebrand factor multimers. 


\section{References}

1. Greer, M.A., Disorders of the thyroid. In: Stein, J.H. (ed.) Internal Medicine, second edition, Little Brown and Company, Boston, Toronto, 1987, pp. 1918-1940.

2. Hoffenberg, R. Thyroid disorders. In: Wetherall, D.J., Ledingham, J.G.G. \& Warrell, D.A. (eds) Oxford Textbook of Medicine, second edition. Oxford Medical Publications, Oxford, 1987, pp. 10.30-10.48.

3. Horton, L., Coburn, R.J., England, J.M. \& Himsworth, R.L. The haematology of hypothyroidism. Q J Med (New Series) 1976, 177: 101-124.

4. Orr, F.R. Haemorrhage in myxoedema coma. Lancet, 1962, ii: $1012-1015$.

5. Egeberg, $O$. Influence of thyroid function on the blood clotting system. Scand J Clin Lab Invest 1963, 15: 1-7.

6. Dalton, R.G., Dewar, M.S., Savidge, G.F. et al. Hypothyroidism as a cause of acquired von Willebrand's disease. Lancet 1987, i: 1007-1009.

7. Pitney, W.R. \& Brozovic, M. In: Dacie, J.V. \& Lewis, S.M (eds) Practical Haematology, sixth edition. Churchill Livingstone, Edinburgh, 1984, pp. 208-223.

8. Hardisty, R.M. \& MacPherson, J.C. A one-stage factor VIII (anti-haemophiliac globulin) assay and its use in venous and capillary plasma. Thromb Diath Haem 1962, 7: 215-219.

9. Zimmerman, T.S., Hoyer, L.W., Dickson, L. \& Edington, T.S. Determination of the von Willebrand's disease antigen (factor VIII-related antigen) in plasma by quantitative immunoelectrophoresis. J Lab Clin Med 1975, 86: 152-155.

10. Weiss, H.J., Rogers, J. \& Brand, H. Properties of the platelet retention (von Willebrand) factor and its similarity to the antihemophilic factor (AHF). Blood 1973, 41: 809-815.
11. Ruggeri, Z.M. \& Zimmerman, T.S. The complex multimeric composition of factor VIII/von Willebrand factor. Blood 1981, 57: 1140-1143.

12. Enayat, M.S. \& Hill, F.G.H. Analysis of the complexity of the multimeric structure of factor VIII related antigen/von Willebrand protein using a modified electrophoretic technique. J Clin Pathol 1983, 36: 915-919.

13. Simone, J.V., Cornet, J.A. \& Abildgaard, C.F. Acquired von Willebrand's syndrome in systemic lupus erythematosus. Blood 1968, 31: 806-812.

14. Ingram, G.I.C., Kingston, P.J., Leslie, J. \& Bowie, E.J.W. Four cases of acquired von Willebrand's syndrome. $B r J$ Haematol 1983, 54: 189-199.

15. Zetterwall, O. \& Nilsson, I.M. Acquired von Willebrand's disease caused by a monoclonal antibody. Acta Med Scand 1978, 204: 521-528.

16. Sampson, B.M., Greaves, M., Malia, R.G. \& Preston, F.E. Acquired von Willebrand's disease: demonstration of a circulating inhibitor to the factor VIII complex in four cases. Br J Haematol 1983, 54: 233-244.

17. Takahasi, H., Yamada, M. \& Shibata, A. Acquired von Willebrand's disease in hypothyroidism (Letter). Thromb Haemost 1987, 58: 1095.

18. Oppenheimer, J. Thyroid hormone action at the cellular level. Science 1979, 203: 971-974. 